\title{
Short Communication: Leaf architectural analysis of confusing Syzygium species: Syzygium aqueum (Burm.f.) Alston and Syzygium samarangense (Blume) Merr. \& L.M.Perry (Myrtaceae)
}

\author{
JOSE DALE L. VIACRUCIS III ${ }^{1, \boldsymbol{v}}$, INOCENCIO E. BUOT JR ${ }^{2}$ \\ ${ }^{1}$ Graduate School, University of the Philippines Los Baños, College, Batong Malake, Los Baños, Laguna 4031, Philippines. Tel.: +63-926-705-4639, \\ "email: jlviacrucis@up.edu.ph \\ ${ }^{2}$ Institute of Biological Sciences, College of Arts and Sciences, University of the Philippines Los Baños, College, Batong Malake, Los Baños, Laguna \\ 4031, Philippines
}

Manuscript received: 21 January 2021. Revision accepted: 25 May 2021.

\begin{abstract}
Viacrucis III JDL, Buot Jr. IE. 2021. Short Communication: Leaf architectural analysis of confusing Syzygium species: Syzygium aqueum (Burm.f.) Alston and Syzygium samarangense (Blume) Merr. \& L.M.Perry (Myrtaceae). Biodiversitas 22: 33413348. Among species of Myrtaceae family which has economic and ecological importance are the two Syzygium species, Syzygium aqueum and Syzygium samarangense. Both species are cultivated throughout the tropics because of their edible fruits and medicinal properties of various plant parts. However, despite their wide utilization, the two species are often confusing due to their morphological similarity. In this study, leaf architecture of $S$. aqueum and $S$. samarangense have been evaluated to delineate the two confusing taxa. Selected laminal and venation characters were compared. Results showed many similar characters shared between the two species, however, laminar size, apex and base shape, areolation, and freely ending veinlets (FEVs) were found to be distinct. Multivariate analyses, cluster analysis employing Gower similarity index, using unweighted pair-group average (UPGMA) and single linkage (nearest neighbor) algorithm, and ordination using Principal Coordinates Analysis (PCoA), illustrated that they are grouped separately. The variations in laminal and venation characters are additional set of information that will allow accurate differentiation of the two species. However, it is recommended that additional taxonomical analysis using various methods, such as molecular techniques, be employed and characters, such as floral morphology, be studied to contribute in the resolution of the taxonomic complexity of this group and other taxonomic controversies
\end{abstract}

Keywords: Leaf architecture, Syzygium, venation, water apple

\section{INTRODUCTION}

The family Myrtaceae has attained relevance worldwide because it comprises several genera of great economic and ecological importance. It is found commonly in many biodiversity hotspots such as South America, Australia, and tropical Asia, with observed occurrences in Europe and Africa (Grattapaglia et al. 2012). However, despite its relevance and diverse representation in wide range of biomes, Myrtaceae is still considered as a taxonomically complex family (McVaugh 1968; Oliveira et al. 2017). Speciation brought about by hybridization and polyploidy, and lack of anatomical and morphological studies were attributed to the difficulty of identification and delimitation of species (Oliveira et al. 2017)

Among generic groups in Myrtaceae, the genus Syzygium is the largest with an estimated species count in the world of up to 1,200 (Parnell et al. 2007; Govaerts et al. 2008). Its taxonomy has been long disputed with the genus Eugenia. Although morphological, anatomical, and molecular evidences have brought consensus among taxonomists to delineate the genera from one another, conceptual problem within generic and species delimitation within Syzygium still remains a problem (Soh 2017).
Several Syzygium species are considered as important food resource for insects, birds, and small and large mammals (Parnell et al. 2007). Among them are S. aqeuem (Burm. f.) Alstom, and S. samarengense (Blume) Merr. \& L.M. Perry. Syzygium aqueum, known as water apple and watery rose apple, is an economic plant that grows and is cultivated throughout the tropics. In the Philippines, it is locally known as tambis (Panggabean 1992). Traditionally, various parts of the plant have been used as medicine, in particular, as an antibiotic (Manaharan et al. 2011). The powdered dried leaves are used as treatments for cracked tongue and the roots have been used to treat itching and swelling (Osman et al. 2009). Moreover, the leaf extracts were reported to have cosmeceutical properties, such as antioxidant, lipolytic, antityrosinase, and anticellulite activies (Palanisamy et al. 2011). On the other hand, $S$. samarangense is another species of Syzygium which bear edible fruits. It is commonly known as wax apple and is the most popular in Southeast Asia because of its economic relevance (Moneruzzaman et al. 2012). In the Philippines, it is most widely known as macopa or makopa (Morton 1987). However, due to their similarity in appearance, $S$. aqueum and $S$. samarangense are often confused with one another (Janick and Paull 2008). 
Taxonomic references, such as on morphological characterization of leaves, especially for widely used economic plants as the aforementioned Syzygium species, are important for authentication and ultimate identification. These references allow verification and accurate identification of plant species, eliminating confusion and improper use of a particular species, particularly as medicine or cosmetics, which could have adverse effects to health, ecology, and sustainability of plant resource (Oliveira et al. 2017). The aim of this paper is to differentiate the two Syzygium species, S. aqueum and $S$. samarangense, using leaf characters to contribute to the knowledge of Syzygium taxonomy and aid in the resolution of morphological confusion.

In this study, leaf architectural features were investigated to differentiate representative species, $S$. aqueum and $S$. samarangense. It was aimed to provide an alternative in differentiating the two confusing taxa and hopefully, contribute to the differentiation of problematic taxonomic groups in the genus Syzygium.

\section{MATERIALS AND METHODS}

\section{Sample collection and preparation}

Twenty-five (25) mature, fully expanded leaves of $S$. aquem and S. Samarangense were collected. To represent the outgroup, Psidium guajava leaf samples were also procured. Identification of samples was assisted by locals in Palompon, Leyte and verified by consulting available related publications. A total of 75 leaves were collected. The collected leaves were orderly placed in a tabloid size newspaper, placed in plant press, and sun-dried for two weeks. The representative samples were herborized following standard herbarium procedures and deposited in the Plant Biology Division Herbarium (PBDH) located at Biological Sciences Building, University of the Philippines Los Baños.

\section{Analysis of leaf architecture}

Analyses of leaf architecture were done on the leaf samples of S. aqueum, S. samarangense, and P. guajava (outgroup). Characters and terminologies of Ellis (2009) were used. Laminal characters evaluated include leaf attachment, leaf arrangement, leaf width, leaf length, leaf area, leaf size, leaf shape, leaf symmetry, margin type, apex angle, apex shape, base angle, and base shape. Venation characters were primary vein framework, major secondary vein framework, major secondary spacing, third vein category, third vein course, quarternary vein category, areolation, and freely ending veinlets.

Parameters such as length and width were done using a transparent ruler, while angles of divergence were measured using a protractor. Analysis of smaller vein patterns were done using a crafted light box. A light box was made using a 16 in $\times 7.5$ in box covered with plastic sheet measured 17 in $x 12$ in. in dimension. A light source was placed inside. The leaves were then pressed in the plastic sheet hanging on the top of the light box. The light passing through the dried leaf specimens allowed easy visualization of the higher vein orders.

\section{Statistical analysis}

A total of 25 leaf characters were observed for each of the leaf samples of $S$. aquem, S. samarangense, and $P$. guajava to investigate their character differences. Qualitative data were assigned with numerical value. To illustrate the relationship of similar leaf architectural traits, cluster analysis was done using two algorithms, unweighted paired group average (UPGMA) and single linkage (nearest neighbor) computed with Gower similarity index. Computations had bootstrap value of 1000 . Moreover, to illustrate the individual differences of Syzygium species, ordination analysis using Principal Components Analysis (PCoA) was also done. Statistical analyses were done using PAST (Paleontological Statistical Software) software by Hammer et al. 2001.

\section{RESULTS AND DISCUSSION}

\section{Leaf characteristics of $S$. aqueum, S. samarangense, and P. guajava}

Leaf samples of $S$. aqueum, $S$. samarangense, and $P$. guajava (outgroup), shown in Figure 1, were evaluated. General laminar characters evaluated were listed in Table 1. As observed, both species shared many similar laminar features. All leaf samples, including the outgroup, were observed to have pinnately compound, opposite leaves. These characters are commonly observed in most species under Myrtaceae family. Symmetrical leaves with elliptic shape, entire margin, and acute apices were also observed across the species analyzed. The same features were exhibited by $P$. guajava leaves except for its obtuse apex.

Dissimilar laminar characters of $S$. aqueum and $S$. samarangense include the laminar size, apex shape and base shape. Leaf samples of $S$. samarangense have distinct larger laminar areas and were categorized as megaphylls (> $164,025 \mathrm{~mm}^{2}$ ), while $S$. aqueum samples were smaller and were categorized as mesophylls $\left(4,500-18,225 \mathrm{~mm}^{2}\right)$. The outgroup, $P$. guajava, were distinctly smaller and some samples were categorized as notophylls $(2,025-4,500$ $\mathrm{mm}^{2}$ ). Similar acute base angles were exhibited by both species. However, difference in base shapes was observed. $S$. aqueum has rounded base shape, while $S$. samarangense has a decurrent shape. 


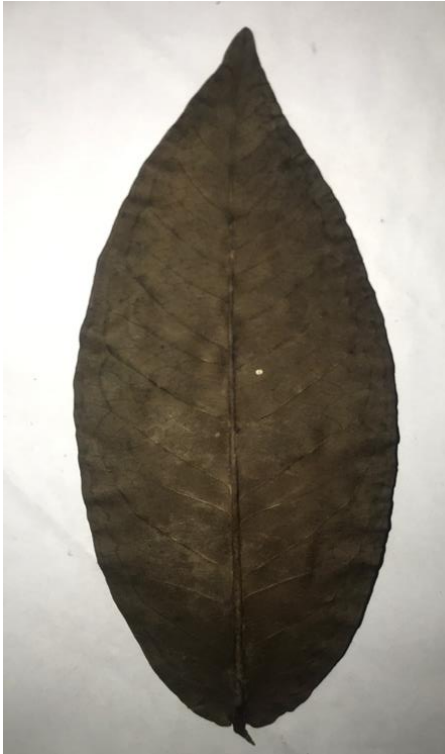

A

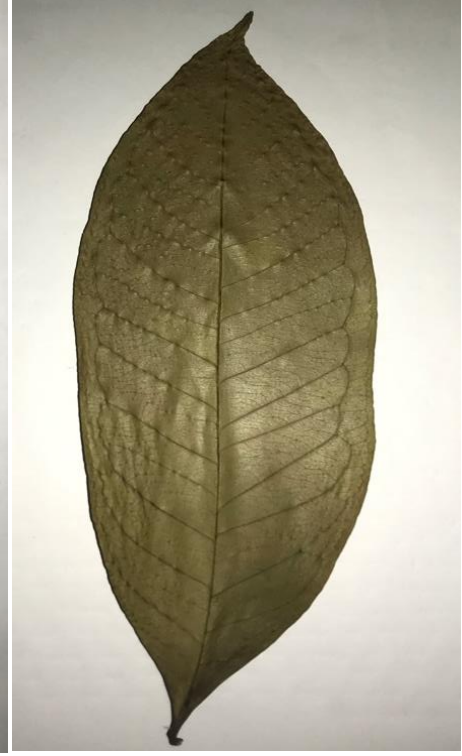

B

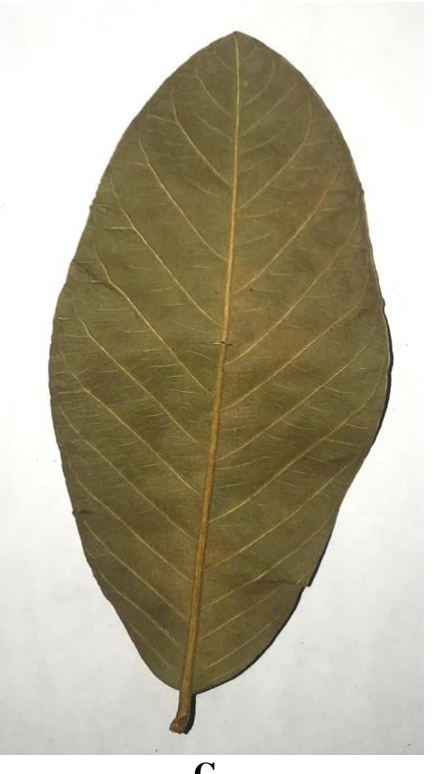

C

Figure 1. Leaf samples of Syzygium aqueum (A), S. samarangense (B), and the outgroup Psidium guajava (C) Exsicc. Viacrucis 7237, 7238, $7239(\mathrm{PBDH})$

Table 1. Laminar characters of Syzygium aqueum and S. samarangense

\begin{tabular}{llll}
\hline Characters & S. aqueum & S. samarangense & P. guajava \\
\hline Leaf attachment & Opposite & Opposite & Opposite \\
Leaf arrangement & Simple & Simple & Simple \\
Laminar width & $6.2-8.0$ & $6.2-10.3$ & $3.3-5.7$ \\
Laminar length & $14.8-19.5$ & $21.0-29.3$ & $9.2-11.5$ \\
Laminar area & $97.02-156.04$ & $130.2-265.05$ & $37.95-58.71$ \\
Laminar size & Mesophyll & Mesophyll-megaphyll & Notophyll-mesophyll \\
Laminar shape & Elliptic & Elliptic & Elliptic \\
Laminar symmetry & Symmetrical & Symmetrical & Symmetrical \\
Margin type & Entire & Entire & Entire \\
Apex angle & Acute & Acute & Obtuse \\
Apex shape & Convex & Acuminate & Convex \\
Base angle & Acute & Acute & Acute \\
Base shape & Rounded & Decurrent & Rounded \\
\hline
\end{tabular}

\section{Venation characters of $S$. aqueum, S. samarangense, and $P$. guajava}

Venation characters of S. aqueum and S. samarangense leaf samples were also observed and compared as shown in Figure 2. The summary of the observed characters was listed in Table 2. Syzygium aqueum and S. samarangense exhibited many similar venation characters. Both exhibited pinnate primary vein framework, festooned brochidodromous secondary vein framework, and irregular secondary spacing. The secondary angles in both species were smoothly decreased towards base. Similar vein category and third vein course were exhibited by both species, having alternate percurrent and sinuous characters, respectively. Random reticulate quarternary vein category was also observed in $S$. aqueum and $S$. samarangense. According to Oliveira et al. (2011), camptodromousbrochidodromous secondary venation pattern, ultimate marginal venation in arches, and reticulate tertiary venation were common character occurrences in most of the species under Myrtaceae family. Ultimate marginal venation in arches was observed in all species analyzed, although more prominent in S. aqueum and S. samarangense. However, reticulate tertiary venation was only observed in the outgroup, $P$. guajava.

Although many similar venation characters were observed in $S$. aqueum and $S$. samarangense species, differences in their areolation and freely ending veinlets (FEVs) are evident. Areoles are considered the smallest areas of the leaf tissue, which are surrounded by quaternary and quinary vein orders. A well-developed areolation was observed in $S$. aqueum leaf samples, while moderately developed areolation was exhibited by $S$. samarangense. Furthermore, FEVs are branched in S. samarangense, and absent in $S$. aqueum. The outgroup exhibited a lot of different venation characters, such as the major secondary vein framework, major secondary angle, and the third vein course. 


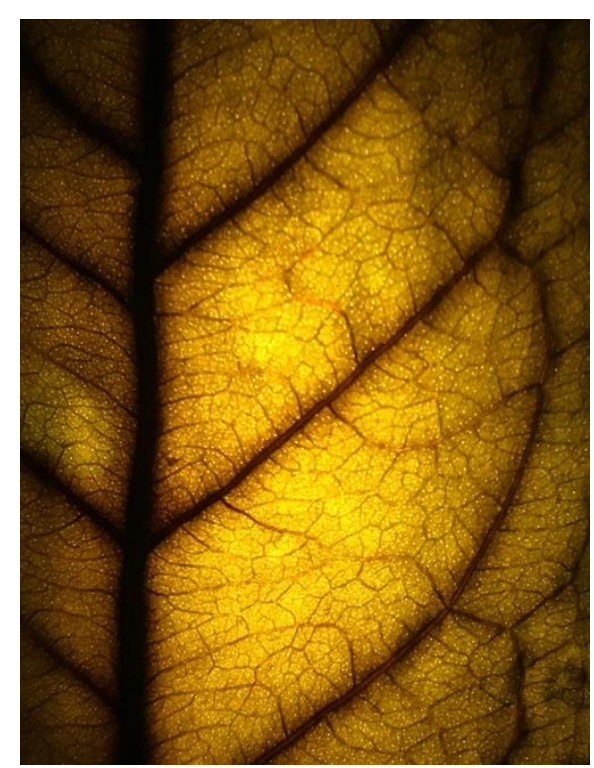

A

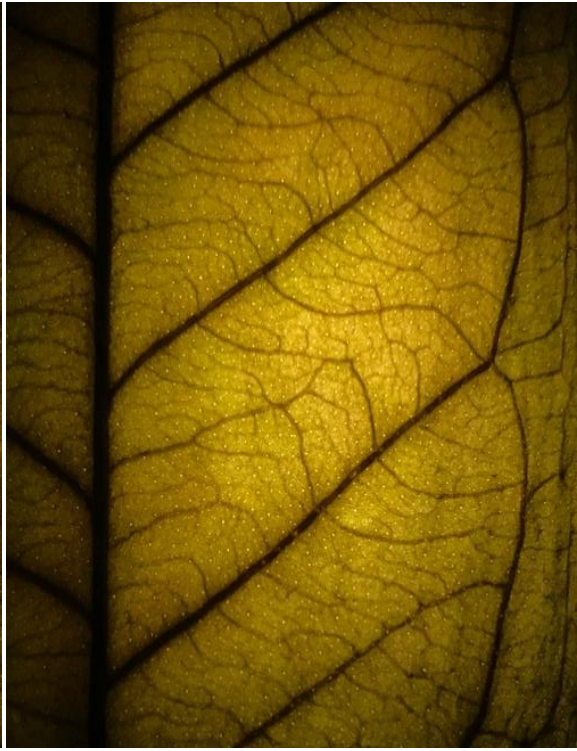

B

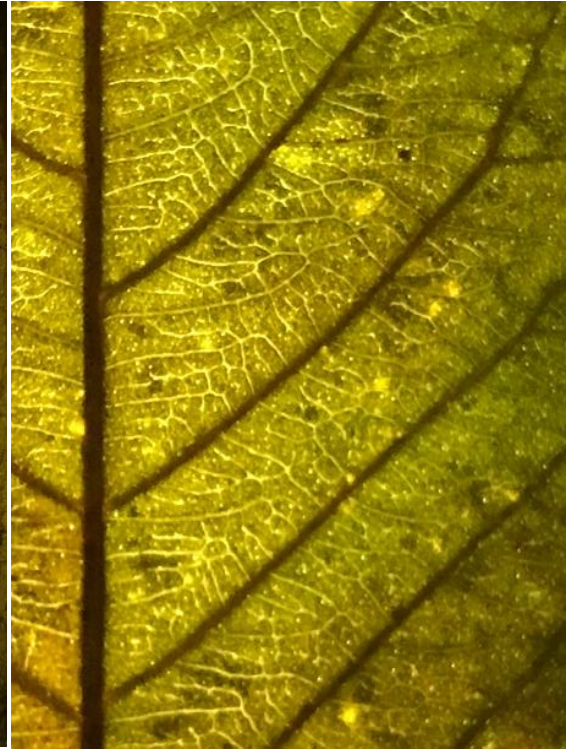

C

Figure 2. Venation characters of the leaves of Syzygium aqueum (A), S. samarangense (B), and the outgroup Psidium guajava (C), showing their higher vein orders.

Table 2. Venation characteristics of Syzygium aqueum, S. Samarangense, and Psidium guajava

\begin{tabular}{|c|c|c|c|}
\hline Characters & S. aqueum & S. samarangense & P. guajava \\
\hline Primary vein framework & Pinnate & Pinnate & Pinnate \\
\hline $\begin{array}{l}\text { Major secondary vein } \\
\text { framework }\end{array}$ & Festooned brochidodromous & Festooned brochidodromous & Weak brochidodromous \\
\hline Major secondary spacing & Irregular & Irregular & Irregular \\
\hline Major secondary angle & $\begin{array}{l}\text { Smoothly decreasing towards } \\
\text { base }\end{array}$ & $\begin{array}{l}\text { Smoothly decreasing towards } \\
\text { base }\end{array}$ & Uniform \\
\hline Third vein category & Alternate percurrent & Alternate percurrent & Random reticulate \\
\hline Third vein course & Sinuous & Sinuous & Ramified \\
\hline Quarternary vein category & Regular polygonal reticulate & Regular polygonal reticulate & Regular polygonal reticulate \\
\hline Areolation & Well developed & Moderately developed & Moderately developed \\
\hline Freely-ending veinlets (FEVs) & Absent & Branched & Branched \\
\hline
\end{tabular}

Dissimilar laminar and venation characters that could be used to distinguish $S$. aqueum and S. samarangense from each other are summarized in Table 3. Distinctive characters of $S$. aqueum and $S$. samarangense are the laminar size, apex, base, areolation, and FEVs. Reports have showed that these distinctive characters can be used as taxonomic characters at species level. For instance, distinct areolation among species have been reported to be one of the most useful leaf characters used as taxonomic tool for delimitation, as seen in the study of Khaya species by Oyedapo et al. (2018) and Philippine Dipterocarpus species by Hernandez et al. (2020). Moreover, taxonomic significance of leaf apex shape and size have also been elucidated by studies of Shorea species by Khan et al. (2016) and Pulan and Buot (2014).

\section{Statistical analysis of leaf architectural characteristics of S. aqueum, S. samarangense, and P. guajava}

Similarities and dissimilarities of the laminar and venation characters of plant species analyzed were visually shown in output patterns using multivariate analysis data exploration. Dendograms using unweighted pair-group average (UPGMA) and single linkage (nearest neighbor) algorithm evidently illustrate the distinction between $S$. aqueum, $S$. samarangense, and $P$. guajava (outgroup) (Figures 3 and 4). Despite showing several branching within the group, all 25 leaf samples of $S$. aqueum, $S$. samarangense, and $P$. guajava were clustered together. Even with limited dissimilar characters, the analysis showed that all species exhibit variability in the laminal and venation characters, and thus are distinct from one another. The study agreed with the findings of RothNebelsick et al. (2001) and many others (Buot 2020; Paguntalan and Buot 2019; Baltazar and Buot 2019a; Baltazar and Buot 2019b; Baltazar and Buot 2019c) that leaf architectural characters are genetically fixed and hence, can be used favorably in taxonomic studies, especially when dealing with controversial taxa as $S$. aqueum and $S$. samarangense. 
Moreover, PCOa data ordination (Figure 5) showed variation among characters of the leaf samples studied. As observed, the species clustered distinctly in groups indicating relevant variabilities between laminal and venation characters of $S$. aqueum and $S$. samarangense. The outgroup, $P$. guajava, has the most distinct cluster between the two indicating strong variability among the two Syzygium species.

Table 3. Opposing laminar and venation characters of Syzygium aqueum and S. samarangense

\begin{tabular}{llll}
\hline Characters & S. aqueum & S. samarangense & P. guajava \\
\hline Laminar size & Mesophyll & Mesophyll-megaphyll & Notophyll-mesophyll \\
Apex shape & Convex & Acuminate & Convex \\
Base shape & Rounded & Decurrent & Rounded \\
Areolation & Well developed & Moderately developed & Moderately developed \\
Freely-ending veinlets (FEVs) & Absent & Branched & Branched \\
\hline
\end{tabular}

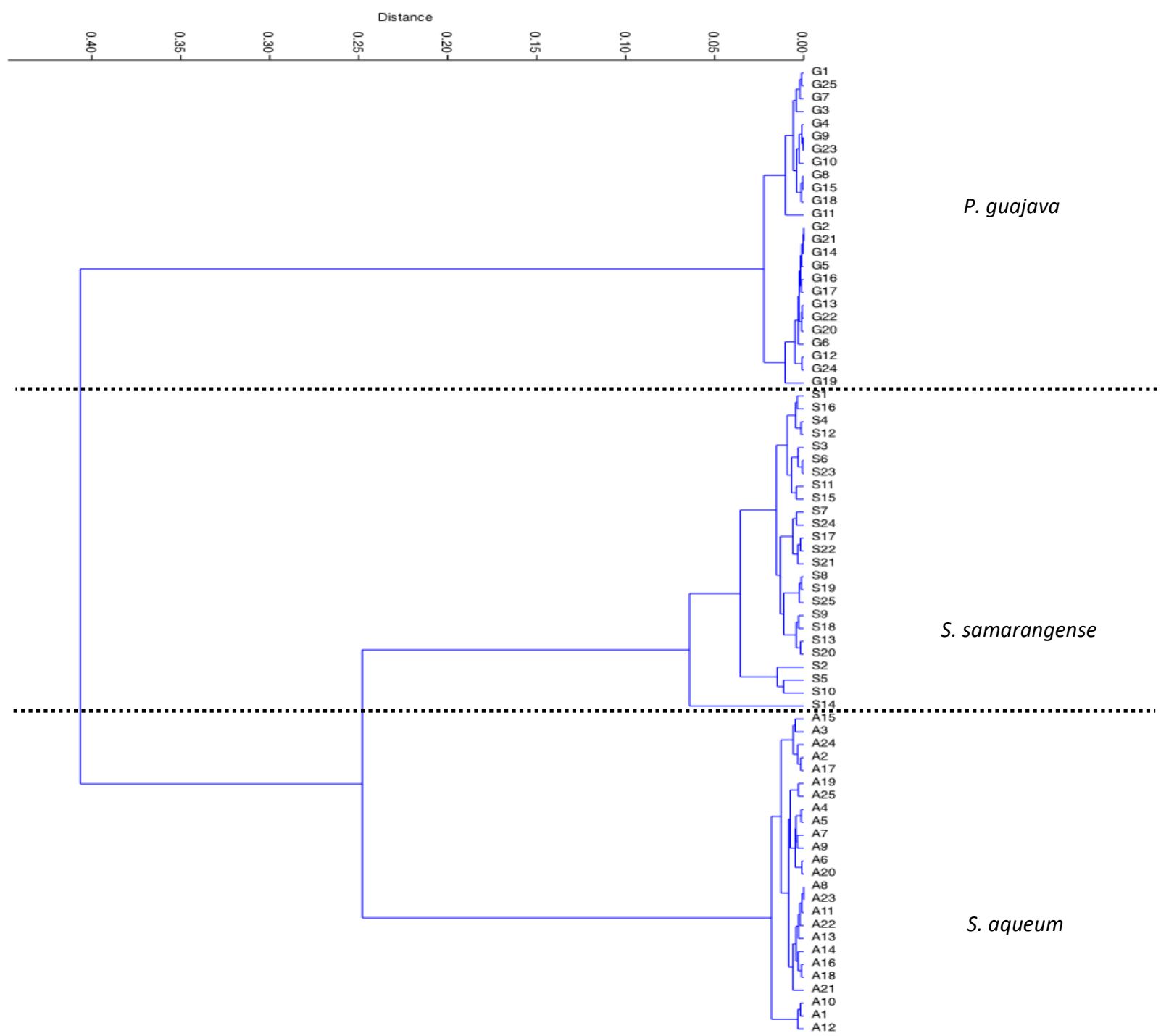

Figure 3. Dendrogram generated using unweighted pair-group average (UPGMA) clustering approach for Syzygium aqueum, S. samarangense, and Psidium guajava (outgroup), showing distinct clusters, thus exhibiting variability in the laminal and venation characters 


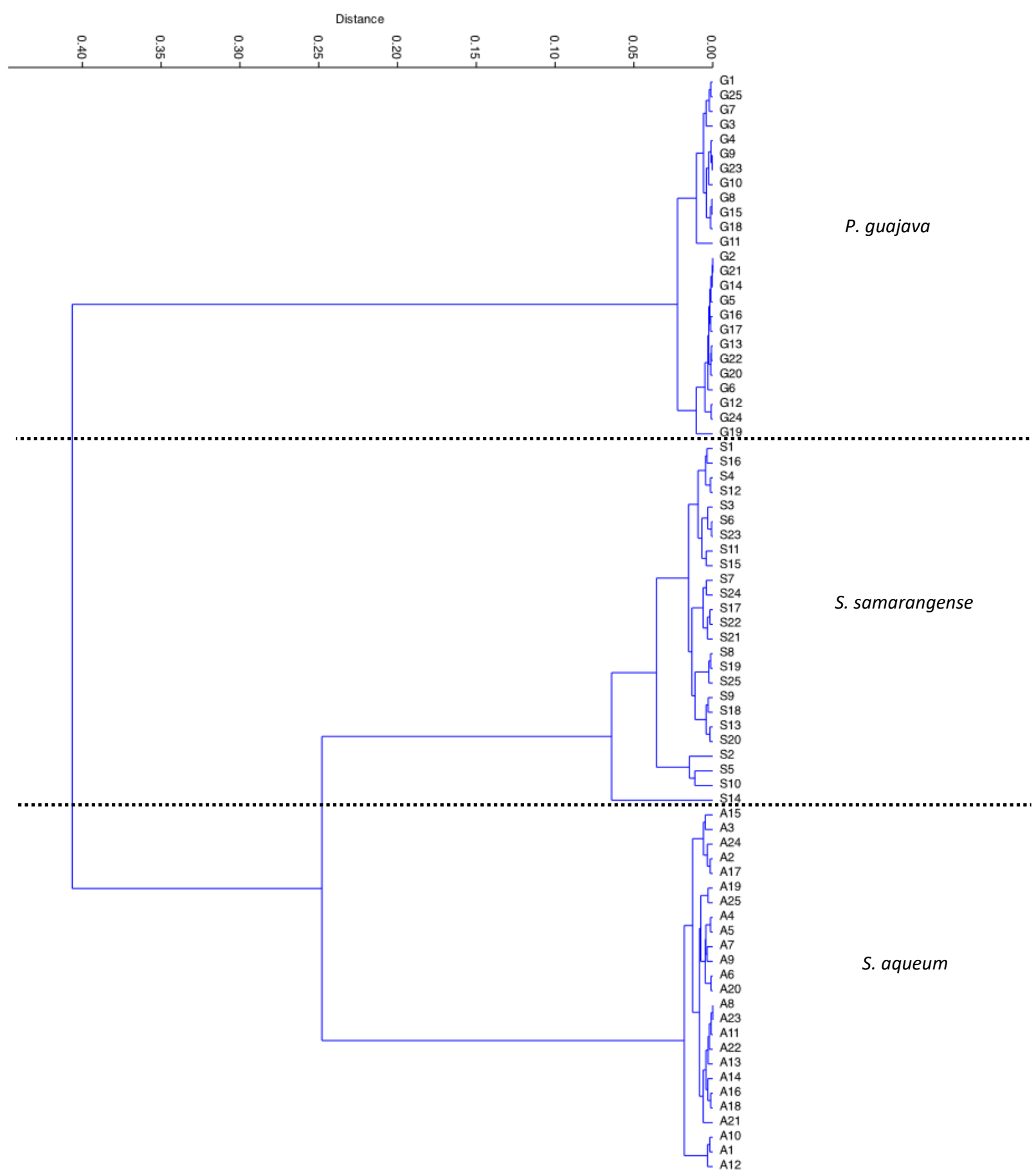

Figure 4. Dendogram generated using single-linkage clustering approach for Syzygium aqueum, S. samarangense, and Psidium guajava (outgroup), showing distinct clusters, expressing variability on laminar and venation characters 


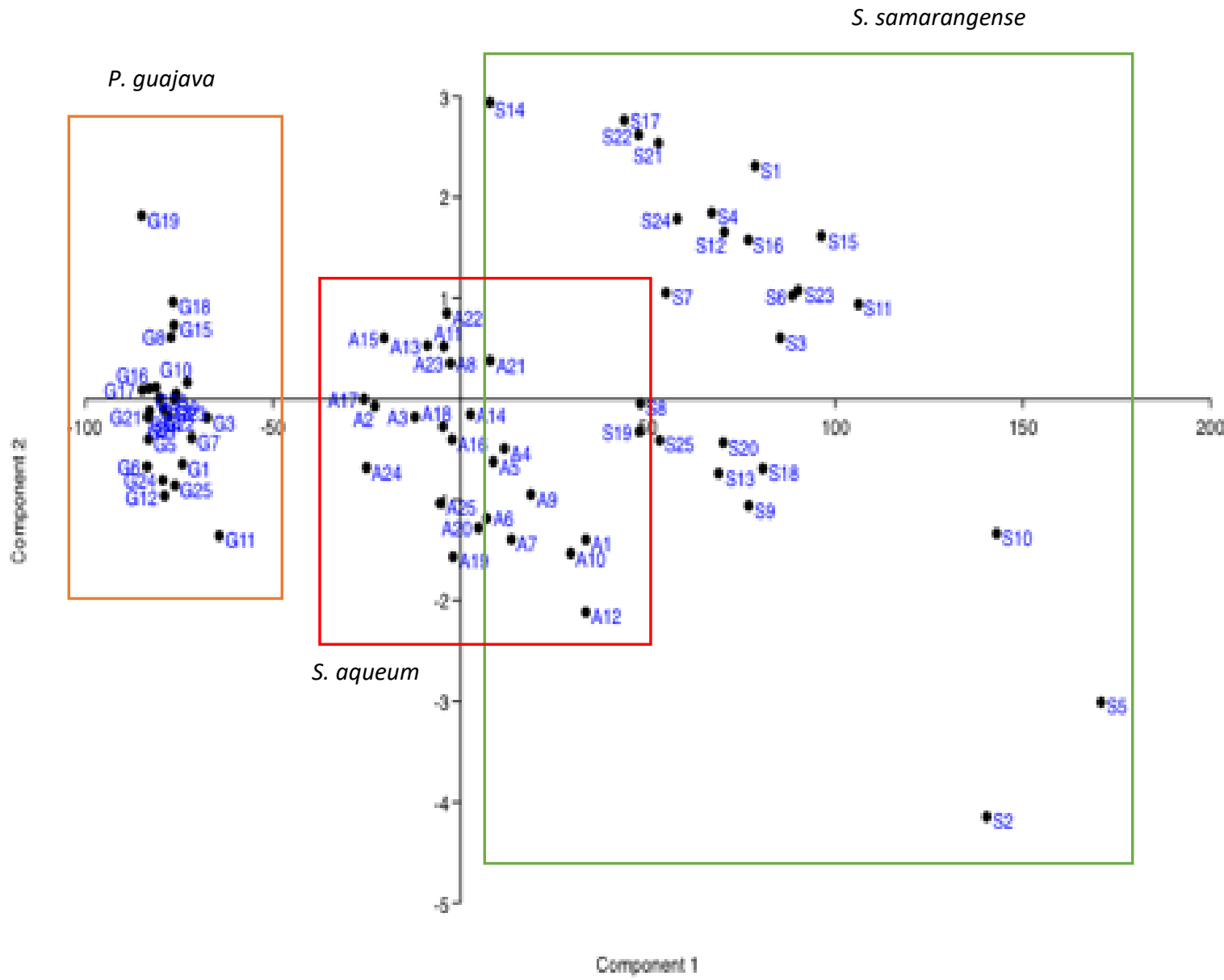

Figure 5. Principal Component Analysis (PCoA) for Syzygium aqueum, S. samarangense, and Psidium guajava (outgroup), showing distinct groups, further validating the distinction of laminar and venation characters.

\section{Discussion}

With respect to the biodiversity reported for the Syzygium and the described taxonomic complexity of this genus by Oliveira et al. (2017), there is an evident need for comprehensive taxonomic studies on species under this group. Morphological studies of this family, and especially of genus Syzygium, could contribute to future phytosociological and ecological studies and provide further evidences to validate taxonomic classification of the group and new species recognition (Oliveira et al. 2017).

In conclusion, laminar and venation characters of $S$. aqueum, S. samarangense, and P. guajava (outgroup) were evaluated to delineate the two taxonomically confusing species. In this study, S. aqueum and $S$. samarangense shared many similar characters which adds to the confusion of the two species, however, they were found to be different in terms of laminar size, apex shape, base shape, areolation, and FEVs. Cluster analyses, using unweighted pair-group average (UPGMA) and single linkage (nearest neighbor) algorithms, and ordination multivariate analyses evidently illustrated the distinction of the two taxa. The variations in laminar and venation characters are additional set of information that will allow accurate delineation of the two species.

Leaf architecture is shown to be a good taxonomic marker and is a useful tool to confirm and identify distinct species using physical characters, such as general laminar and venation characters. With respect to this study, it is suggested that floral characters of $S$. aqueum and $S$. samarangense should be delineated to highlight distinction between species. It is also recommended that taxonomical analysis using various methods, such as molecular techniques, be employed in more Syzygium species to contribute in the resolution of the taxonomic complexity of this group and other taxonomic controversies.

\section{ACKNOWLEDGEMENTS}

The authors would like to thank locals in the municipality of Palompon in Leyte, Philippines who have extended their assistance in locating and gathering the leaf samples used in the study. 


\section{REFERENCES}

Baltazar AM, Buot IE Jr. 2019a. Controversies on Hoya R. Br. Taxonomy. Thail Nat Hist Mus J 13 (1): 59-68.

Baltazar AM, Buot IE Jr. 2019b. Leaf architectural analysis of taxonomic confusing coffee species: Coffea liberica and Coffea liberica var. dewevrei. Biodiversitas 20 (6): 1560-1567. DOI: 10.13057/biodiv/d200611.

Baltazar AM, Buot IE Jr. 2019c. Resolving taxonomic confusion between Hoya cumingiana Decne. and Hoya densifolia Turcz. (Apocynaceae) using Leaf Architectural Analysis. Thail Nat Hist Mus J 13 (2): 77 89

Buot IE Jr. 2020. Leaf architecture as a promising tool in confirming identity of confusing plant taxa. J Nat Stud 19 (1): 134-143.

Ellis B. 2009. Manual of Leaf Architecture. Published in association with the New York Botanical Garden, Bronx, NY.

Grattapaglia D, Vaillancourt RE, Shepherd M, Thumma BR, Foley W, Külheim C, Potts BM, Myburg AA. 2012. Progress in Myrtaceae genetics and genomics: Eucalyptus as the pivotal genus. Tree Gen Genomes 8 (3): 463-508. DOI: 10.1007/s11295-012-0491-x.

Govaerts R, Sobral M, Ashton P, Barrie F, Holst BK, Landrum LL, Matsumoto K, Mazine FF, Lughadha EN, Proenca C, Soares-Silva LH, Wilson PG, Lucas E. 2008. World checklist of Myrtaceae. Royal Botanic Gardens, Kew, UK.

Hammer $\varnothing$, Harper DA, Ryan PD 2001. PAST: Paleontological statistics software package for education and data analysis. Palaeontol Electronica 4 (1): 9.

Hernandez JO, Maldia LS, Pulan DE, Buot Jr, IE, Park BB. 2020. Leaf architecture and petiole anatomy of Philippine Dipterocarpus species (Dipterocarpaceae). Bangladesh J Plant Taxon 27 (1): 1-14. DOI: 10.3329/bjpt.v27i1.47564.

Janick J, Paull RE (eds). 2008. The Encyclopedia of Fruit and Nuts CABI, Wallingford, UK. DOI: 10.1079/9780851996387.0000

Khan MA, Spicer RA, Spicer TE, Bera S. 2016. Occurrence of Shorea Roxburgh ex CF Gaertner (Dipterocarpaceae) in the Neogene Siwalik forests of eastern Himalaya and its biogeography during the Cenozoic of Southeast Asia. Rev Palaeobot Palynol 233: 236-254. DOI: 10.1016/j.revpalbo.2016.07.011.

Manaharan T, Appleton D, Cheng HM, Palanisamy UD 2012. Flavonoids isolated from Syzygium aqueum leaf extract as potentia antihyperglycaemic agents. Food Chem 132 (4): 1802-1807. DOI: 10.1016/j.foodchem.2011.11.147

McVaugh R. 1968. The genera of American Myrtaceae: an interim report Taxon 17 (4): 354-418. DOI: 10.2307/1217393.

Moneruzzaman KM, Nasrulhaq BA, Osman N, Sharif HABM. 2012. Physiochemical and phytochemical properties of wax apple
(Syzygium samarangense [Blume] Merrill \& LM Perry var. Jambu Madu) as affected by growth regulator application. Sci World J 2012. DOI: $10.1100 / 2012 / 728613$

Morton JF. 1987. Fruits of Warm Climates. JF Morton, Miami, FL.

Osman H, Rahim AA, Isa NM, Bakhir NM. 2009. Antioxidant activity and phenolic content of Paederia foetida and Syzygium aqueum. Molecules 14 (3): 970-978. DOI: 10.3390/molecules14030970.

Oliveira MIU, Funch LS, Santos F, Landrum L. R. 2011. Application of morpho-anatomical leaf characters in Campomanesia Ruiz \& Pavón (Myrtaceae) taxonomy. Acta Bot Bras 25 (2): 455-465. DOI: 10.1590/S0102-33062011000200021.

Oliveira EF, Bezerra DG, Santos ML, Rezende MH, Paula JÁ. 2017. Leaf morphology and venation of Psidium species from the Brazilian Savanna. Rev Bras Farmacog 27 (4): 407-413. DOI: 10.1016/j.bjp.2017.03.005.

Oyedapo OA, Agbedahunsi JM, Illoh HC, Akinloye AJ. 2018. Comparative foliar anatomy of three Khaya species (Meliaceae) used in Nigeria as antisickling agent. Sci Cold Arid Regions 10 (4): 279285.

Paguntalan DP, Buot IE Jr. 2019. Short Communication: Investigation of leaf architectural patterns: Implications in delineating taxonomically controversial Hoya merrillii Schlechter and Hoya quinquenervia Warburg. Biodiversitas 20 (3): 833-839. DOI: 10.13057/biodiv/d200329.

Roth-Nebelsick A, Uhl D, Mosbbrugger V, Kerp H. 2001. Evolution and function of leaf venation architecture: A review. Ann Bot 87 (5): $553-$ 566. DOI: 10.1006/anbo.2001.1391.

Panggabean G. 1992. Syzygium aqueum (Burm.f) Alston, Syzygium malaccense (L.) Merr.\& Perry, Syzygium samarangense (Blume) Merr.\& Perry. In: Verheij EWM, Coronel RE (eds.). Plant Resources of South-East Asia 2: Edible fruits and nuts. Prosea, Bogor.

Palanisamy UD, Ling LT, Manaharan T, Appleton D. 2011. Rapid isolation of geraniin from Nephelium lappaceum rind waste and its anti-hyperglycemic activity. Food Chem 127 (1): 21-27. DOI: 10.1016/j.foodchem.2010.12.070

Parnell JAN, Craven LA, Biffin E. 2007. Matters of scale: dealing with one of the largest genera of angiosperms. In Reconstructing the tree of life: Taxonomy and systematics of species rich taxa. CRC Press LLC, Boca Raton, FL. DOI: 10.1201/9781420009538.ch16.

Pulan DE, Buot Jr IE. 2014. Leaf architecture of Philippine Shorea species (Dipterocarpaceae). Intl Res J Biol Sci 3 (5): 19-26.

Soh WK 2017. Taxonomy of Syzygium. In: Nair KN (ed) The Genus Syzygium: Syzygium cumini and Other Underutilized Species. CRC Press, New York. DOI: 10.1201/9781315118772-1. 